\title{
studia medioznawcze
}

2020, tom 21, nr 2 (81)

ISSN 2451-1617

\section{Irracjonalizm w zmediatyzowanym społeczeństwie wiedzy}

\section{Ramowanie, słownik, retoryka, ikonografia}

\author{
Małgorzata Lisowska-Magdziarz \\ Uniwersytet Jagielloński, Kraków \\ malgorzata.lisowska-magdziarz@uj.edu.pl \\ ORCID: 0000-0003-2351-738X
}

STRESZCZENIE

Cel/teza: Identyfikacja ram konceptualnych nauki i wiedzy naukowej w komunikowaniu organizacji i jednostek otwarcie walczących z oficjalną wersją wiedzy naukowej: przeciwników szczepień ochronnych, proponentów teorii płaskiej ziemi oraz zwolenników alternatywnej wersji historii Polski. Metody badawcze: Opierając się na wcześniejszej konceptualizacji, użyto analizy zawartości opartej na modelu dyskursywnym oraz narzędzi analizy ramowania. Wyniki i wnioski: Zlokalizowano w badanym materiale cztery główne ramy interpretacyjne oraz cztery modelowe stylistyki. Wnioski dotyczą względnie jednolitego ramowania zagadnienia wiedzy w komunikacji grup antynaukowych, niezależnie od ich głównego celu, a także wzajemnego przenikania się ich argumentacji. Dostrzeżono także fenomen irracjonalizmu banalnego - postaw antyracjonalnych i antynaukowych wyrażanych przez uczestników komunikacji medialnej bezwiednie, odruchowo, żartem lub przez nieuwagę. Wartość poznawcza: Wiąże się z diagnostycznym i prognostycznym wymiarem analizy. Swoiste instrumentalne ramowanie nauki i wiedzy to niezbędny element strategii komunikacyjnych zwolenników „wiedzy alternatywnej”, zatem jego analiza powinna pomóc $\mathrm{w}$ dalszych badaniach nad mechanizmami rozpowszechniania antyracjonalizmu $\mathrm{i}$ irracjonalizmu $\mathrm{w}$ mediach. To istotne, ponieważ walka $\mathrm{z}$ antyracjonalizmem w komunikowaniu jest dziś jednym z najważniejszych społecznych zadań medioznawcy.

\section{SŁOWA KLUCZOWE}

analiza ramowania, media społecznościowe, nowoczesność, racjonalność, wiedza naukowa 
B rytyjski historyk nauki Robert Proctor jest autorem pojęcia agnotologii (z gr. agnōsis - 'niewiedza') - nauki o procesach podtrzymywania i wzmacniania społecznej ignorancji i wiedzy fałszywej (Proctor \& Schiebinger, 2008). Termin ,,agnotologia” (lub ,agnatologia”), ukuty z początku częściowo dla żartu, nabrał szybko poważnego charakteru, jako że mamy obecnie do czynienia z nasilonym rozpowszechnianiem się fałszywych informacji, podważaniem wiarygodności wiedzy naukowej opartej na podstawach racjonalnych oraz rozmaitymi formami uprawomocnienia antyracjonalizmu i irracjonalizmu w dyskursie publicznym. Ten paradoks - podważanie paradygmatu racjonalnego w społeczeństwie wiedzy - jest w znacznej mierze genetycznie powiązany z rozwojem mediów interaktywnych. Proctor pisał o tym zresztą, zwracając uwagę na znaczenie publikacji fałszujących wiedzę i wskazując na media jako głównych winowajców agnozji. Zjawisko to jest niebezpieczne, ponieważ obniżanie zaufania do wiedzy naukowej oraz szerzenie antyracjonalizmu i irracjonalizmu tworzą klimat dla rozwoju populizmów, utrudniają rozwiązywanie ważkich problemów społecznych oraz skłaniają ludzi do działań sprzecznych $\mathrm{z}$ ich racjonalnie pojętym interesem.

\section{Irracjonalizm w mediach - zarys projektu badawczego}

Konieczne są w związku z tym badania nad mechanizmami rozpowszechniania informacji i opinii antyracjonalnych i irracjonalnych. Ten projekt badawczy jest powiązany z próbą konceptualizacji i kategoryzacji cech komunikowania irracjonalnego, z myślą o jego dalszym, głębszym poznaniu, jak również o realnej walce $\mathrm{z}$ jego szerzeniem się. Zagadnienie to jest obecnie tematem wielu badań naukowych. Analizują je antropolodzy, psychologowie społeczni, socjolodzy i kognitywiści. Ważne jest, żeby zajęła się nim także nauka o mediach.

O ile dyskurs antyracjonalny jest obecnie względnie zglobalizowany, to jego przejawy mają lokalny charakter, a walka z nim musi mieć charakter miejscowy, dostosowany do kulturalnego kontekstu i charakterystyki różnych systemów medialnych. Opisane w dalszej części tekstu badania miały na celu opis i kategoryzację komunikacyjnych ujęć antynaukowości jako jednej $\mathrm{z}$ podstawowych cech dyskursu irracjonalnego i antyracjonalnego $\mathrm{w}$ polskich mediach. Podjęto próbę zbadania komunikacji polskich zbiorowości, które nie ukrywają wrogości w stosunku do „oficjalnej” wiedzy naukowej lub/oraz jawnie kwestionują formy racjonalności usankcjonowane przez projekt nowoczesny. Powinno to pomóc w dalszych badaniach nad anytracjonalnością w mediach i dostarczyć narzędzi do jej diagnozowania także wówczas, gdy występuje ona w sposób niejednoznaczny lub ukryty, w komunikacji użytkowników mniej agresywnie antyracjonalnych, w miejscach mniej oczywistych, także w sytuacjach niezwiązanych bezpośrednio z negocjowaniem zaufania do nauki.

\section{Racjonalizm, irracjonalizm, antyracjonalizm a wiedza naukowa}

Na wstępie konieczne było rozwiązanie trudnego zagadnienia definicji operacyjnej racjonalizmu i irracjonalności, na ich zaś tle - nauki i antynaukowości. Filozofia nauki mówi o wielu typach racjonalności, wskazując w szczególności na racjonalność teoretyczną i praktyczną, racjonalność zdroworozsądkową i racjonalność naukową, racjonalność wiedzy i działania etc. (Tałasiewicz, 1995, s. 81-92). Jednocześnie jednak epistemologia nie ma uniwersalnie używanej i powszechnie akceptowanej definicji racjonalności (Walczak, 2006, s. 14, 22-23), sam zaś termin jest przedmiotem sporów zarówno na poziomie metateoretycznym, jak podczas jego praktycznych zastosowań w dyskursie publicznym. Spory ideologiczne na ten temat często sprowadzają się do tego, że ludzie używają dla własnych retorycznych celów różnych definicji myślenia (i postępowania) racjonalnego i na tej podstawie zarzucają nieracjonalność oponentom. Na potrzeby niniejszej analizy przyjęto zatem koncepcję racjonalizmu jako cechy myślenia i działania opartego 
na intersubiektywnie sprawdzalnej i empirycznie potwierdzonej nowoczesnej wiedzy naukowej. Dostrzeżono też subtelną, ale istotną różnicę terminologiczną pomiędzy irracjonalizmem - myśleniem i działaniem nieopartym na przesłankach racjonalnych - oraz antyracjonalizmem, czyli symbolicznym lub praktycznym protestem, oporem, walką z myśleniem i działaniem wynikającym z przesłanek racjonalnych. Antyracjonalizm jest w tym ujęciu jednym z aspektów szerzej rozumianej irracjonalności.

Pojęcie irracjonalizmu w mediach zostało więc wstępnie ograniczone. Po pierwsze, zastosowano epistemiczną definicję racjonalności: uznano, za Foleyem (Foley, 1987), że podstawowym racjonalnym celem epistemicznym jest dążenie do posiadania prawdziwych przekonań/prawdziwej wiedzy o świecie oraz unikanie wiedzy i przekonań nieprawdziwych. Za publikacje irracjonalne lub antyracjonalne w mediach uznano te, które promują wiedzę i przekonania nieprawdziwe i zadają kłam przekonaniom i wiedzy prawdziwej, o ile nie zostały opublikowane w mediach z definicji gatunkowo poświęconych fantazji i zmyśleniu (na przykład w serialu fantasy, sesji fotograficznej w anturażu science-fiction czy w telewizyjnej bajce dla dzieci). Po drugie, przyjęto, że sposobem poznania, który najbardziej zbliża do prawdziwej wiedzy i prawdziwych przekonań o świecie jest racjonalne poznanie naukowe. Nie jest ono w żadnym wypadku doskonałe $\mathrm{i}$ - jak słusznie wskazuje na przykład Kuhn (1968) - jest kwestią przyjętego paradygmatu poznawczego, kryteriów oceny koncepcji teoretycznych, praktyki działania wspólnot naukowych w różnych epokach, językach itp. W tej chwili jednak w największej mierze zbliża nas do prawdy o świecie poznawalnym zmysłami oraz przez operacje logiczne. Zainicjowana przez wpływową pracę Thomasa Kuhna i jego prominentnych polemistów Imre Lakatosa (1995) i Paula Feyerabenda (1995) dyskusja na temat warunków uznania prawomocności poznania naukowego, jaka przetoczyła się przez światową filozofię w XX wieku (por. Walczak, 2006, s. 69-81) nie prowadzi ostatecznie do odrzucenia poznania naukowego, lecz raczej do przyjęcia naukowego modelu współczesnego (Tałasiewicz, 1995, s. 97). Przyjmujemy zatem do wiadomości, że naukowy opis zjawiska jest jednocześnie opisem stanu wiedzy badacza w danym momencie i zależy od przyjętych procedur badawczych, a wszelkie wyjaśnienia mają tylko probabilistyczny charakter, niekiedy zaś trzeba akceptować indeterminizm i nieklasyczne wersje logiki. Sceptycyzm jest zatem wyrazem ostrożności, która winna być warunkiem każdej porządnej procedury naukowej. Działa bowiem na rzecz wzmocnienia wartości nauki, nie zaś jej dezawuowania. Niezależnie zaś od wątpliwości i zarzutów, nowoczesna nauka doprowadziła do imponującego przyrostu wiedzy o świecie oraz wielu pozytywnych efektów praktycznych. Założenie, że poznanie naukowe jest optymalnym sposobem uzyskania wartościowej wiedzy o świecie potwierdza się w historii ludzkich osiągnięć i rozwiązań praktycznych, niezależnie od ambiwalentnej niekiedy oceny ich konsekwencji (Pinker, 2018). Gdy chodzi o źródła wiedzy i podstawy pragmatyki, jest to najlepsze, co mamy. To dlatego podważanie ustaleń współczesnej nauki i proponowanie w jej miejsce wiedzy różnych nienaukowych form poznania należy uznać za wielce niebezpieczne.

Bezpośrednie lub pośrednie kwestionowanie prawomocności nowoczesnej wiedzy naukowej oraz wzywanie do działań wynikających z tego podważenia uznano więc za podstawowy wykładnik irracjonalizmu w dyskursie medialnym.

\section{Wiedza naukowa - definicja i operacjonalizacje}

Założenie, że podstawą racjonalizmu jest wiedza naukowa wymagało przyjęcia jej możliwie prostej definicji, łatwej do zastosowania w badaniach. Tymczasem definicja wiedzy naukowej sama w sobie jest przedmiotem sporów wśród filozofów, antropologów i badaczy społeczeństwa. W dodatku rozumienie nauki społecznie może się odnosić do wiedzy naukowej jako takiej, do działań o określonym (naukowym) charakterze oraz do specyficznego obszaru kultury 
(por. Kamiński, 1992, s. 183-184). Generuje to dodatkowy, dobrze znany epistemologii problem demarkacji, czyli oddzielenia nauki od innych form wiedzy i dyskursów w obiegu publicznym (np. sztuki, religii, prawa, moralności). Kryteria racjonalności i naukowości mogą być zatem płynne. Zależą też od tego, czy stosowane są do rodzaju wiedzy, działań czy zbiorowości i jej kultury. Dlatego relacje pomiędzy racjonalnością i nauką nie zostały dotychczas zadowalająco opisane. Definicje nauki odnoszą się do racjonalności, zaś definicje racjonalności każą ją zwykle opierać na poznaniu naukowym; epistemologia, krótko mówiąc, nie jest zgodna co do tego, „która kategoria jest pierwotniejsza, tzn. czy sposób rozumienia nauki wyznacza sposób rozumienia racjonalności, czy też przeciwnie, sposób rozumienia racjonalności wyznacza, co należy uznać za naukę" (Walczak, 2004, s. 353). Konieczne jednak wzajemne powiązanie pomiędzy nauką i racjonalnością nowoczesną pozwoliło na założenie, że antynaukowość jest istotnym, konstytuującym elementem postawy anty- i irracjonalnej, irracjonalizm zaś zawiera w sobie element odrzucenia - z większym lub mniejszym przekonaniem - naukowego poznania świata jako podstawy opisu jego działania oraz motywacji do działań praktycznych. Przyjęta robocza definicja racjonalizmu naukowego została wywiedziona z koncepcji klasycznej (Walczak, 2006, s. 123-124); powszechne, potoczne rozumienie nauki i wiedzy naukowej opiera się bowiem na modelu klasycznym. Ostatecznie więc na potrzeby analizy za wiedzę naukową uznano racjonalną empiryczną wiedzę o świecie skonstruowaną wyniku funkcjonowania paradygmatu nowoczesnego, zatem spełniającą warunki prawdziwości, uzasadnienia, racjonalności, obiektywności, intersubiektywności, metodyczności, uporządkowania, systematyczności, powtarzalności, jednoaspektowości, teoretyczności i praktyczności (tamże, s. 24 i dalsze). Ma to być zatem wiedza świecie wynikająca z realizacji celu, jakim jest odnalezienie obiektywnej prawdy potwierdzonej w obrębie dostępnych nam metod, opartej na sprawdzonych badaniach empirycznych, dokonanych i potwierdzonych za pomocą metodologii intersubiektywnie sprawdzalnych (Kamiński, 1992, s. 11-19), w sposób systematyczny, uporządkowany i powtarzalny. Reliabilizm zatem, przy wszystkich wątpliwościach i kontrowersjach, jakie ze sobą niesie (Ziemińska, 2001), wydaje się dla potrzeb badań i w praktyce społecznej założeniem bezpiecznym, wiarygodnym i racjonalnym. Nowoczesny wymiar tego typu wiedzy wyraża się w tym ujęciu w jej pochodzeniu od badaczy i instytucji do tego celu powołanych, wyposażonych w stosowną do tego celu wiedzę, know-how, doświadczenie i aparaturę badawczą. Wiedza ta ma pozwalać bezpośrednio (paradygmat aplikacyjny) lub pośrednio, długofalowo (badania podstawowe) na rozwiązywanie ludzkich problemów.

\section{Dyskursy paranaukowy, antynaukowy, retoryczny i wojujący}

Przyjmując definicję nauki/naukowości i konceptualizując jej związki z racjonalizmem, autorka niniejszego projektu zdawała sobie sprawę z wartościującego charakteru swoich założeń. Z pełną świadomością przyjęto tu, że ,pojęcie racjonalności stało się w filozofii nauki i epistemologii synonimem tego wszystkiego, co wartościowe poznawczo, co stanowi cel dążeń naukowych i ukierunkowuje uprawianie nauki" (Walczak, 2004, s. 353) - opór zaś przeciwko szerzeniu antynaukowości i irracjonalizmu jest istotnym zadaniem medioznawcy. Media bowiem zawierają w sobie silne nurty antynaukowe i antyracjonalistyczne. Wstępna lektura materiału źródłowego doprowadziła do identyfikacji w mediach dyskursu antynaukowego ukształtowanego w rodzaj kontinuum - zróżnicowanego pod względem celów, kompletności i ciężaru gatunkowego argumentów oraz emocjonalnego nasilenia retoryki. Wypowiedzi antyracjonalistyczne i antynaukowe układają się na nim od najbardziej przypadkowych i niesamoświadomych, do antynaukowości radykalnej, wojującej, nakierowanej na osiągnięcie praktycznych zmian w ludzkich postawach oraz rozwiązaniach społecznych. Dyskurs ten tworzy zarówno komunikacja grup 
antynaukowych, jak komunikacja polityczna, religijna, rozrywka, a nawet informacja, zwłaszcza ta utrzymana w formule infotainment.

- Dyskurs paranaukowy podważa wartość wiedzy naukowej lub propaguje wiedzę obiektywnie fałszywą przy użyciu stylu naukowego, słownika i ikonografii charakterystycznej dla publikacji naukowych, świadectw ekspertów z tytułami naukowymi i używających naukowej argumentacji i terminologii. Materiały paranaukowe mogą wskazywać na bardziej lub mniej precyzyjnie określone źródła naukowe, bądź też odwoływać się do ogólnie ujętych ,badań naukowych”, „ustaleń naukowców”, ,wyników testów klinicznych” (nie wiadomo jednak jakich, gdzie, kiedy). Badania te mogły w istocie nigdy nie zaistnieć lub zostały źle przeprowadzone, lub sfalsyfikowane przez inne, wiarygodne badania, lub zmanipulowane, lub sfałszowane, lub użyte w złej wierze, lub też po prostu są już przestarzałe i nieaktualne. Problem z tego typu publikacjami polega przede wszystkim na tym, że odbiorcy nie są w stanie sprawdzić, czy przytaczane dane są wiarygodne, czy eksperci są wyposażeni w prawdziwą wiedzę (a nawet, czy w ogóle istnieją), a także, czy użyte argumenty naukowe są zastosowane z sensem. Wypowiedzi, teksty, ilustracje wyrażające irracjonalizm paranaukowy nie dezawuują idei nauki samej w sobie - między innymi dlatego, że jej obiektywne znaczenie społeczne jest bardzo wysokie, styl i ikonografia naukowa mają więc spory potencjał perswazyjny.

- Dyskurs antynaukowy natomiast, zawiera podważanie i zaprzeczanie wartości wiedzy naukowej jako takiej lub też prawomocności konkretnej wiedzy naukowej w wybranej dziedzinie. Nauka jest tu radykalnie dezawuowana jako sposób poznania, a wiedza naukowa wskazywana jako niepotrzebna, szkodliwa, niebezpieczna lub grzeszna. Orzeczeniu o jej bezużyteczności lub szkodliwości może towarzyszyć propagowanie alternatywnych form poznania - na przykład intuicji, wiary religijnej, magii - jako lepszych, bardziej moralnych lub bardziej wiarygodnych od nauki.

- Dyskurs retoryczny wyraża się w podważaniu wartości nauki, zaprzeczaniu wiarygodności konkretnej wiedzy naukowej lub propagowaniu wiedzy fałszywej w celu uzyskania celów o charakterze ideologicznym - zmiany społecznych nastawień, opinii, postaw, przekonania odbiorców do określonego światopoglądu, wybranej wersji wydarzenia czy zjawiska, przyjęcia lub kontestacji własnego miejsca w strukturze społecznej i relacjach międzyludzkich. Charakteryzuje się wyraźnym naciskiem perswazyjnym, często też obecnością wezwań do działania (głosowania, protestu, walki, przyłączenia się do działań zbiorowości, podążania za liderem). Retoryczne propagowanie fałszywej wiedzy lub dezawuowanie nauki może się odbywać w celu uzyskania korzyści o charakterze wizerunkowym lub politycznym, ale media robią to też po to, by przypodobać się grupom docelowym i w ten sposób zwiększać czytelnictwo lub klikalność. Wyrazistą odmianą antyracjonalnego dyskursu retorycznego jest dyskurs merkantylny, który cechuje silny nacisk perswazyjny połączony z retoryką paranaukową, stosowany w celu uzyskania korzyści rynkowych. Łatwo go zaobserwować w reklamie, która posługuje się skonwencjonalizowanymi figurami (często nieistniejących) naukowców/ekspertów lub powołuje się na autorytet (prawdziwych lub nie) instytucji badawczych, a także wykorzystuje słownictwo i mechanizmy retoryczne oraz ikonografię typowe dla dyskursu naukowego (hipotezy, dowodzenie, wnioskowanie; laboratoria, eksperymenty, wykłady; wykresy, mapy i schematy). Podważa w ten sposób autorytet nauki, nie tylko przez jej używanie do szerzenia wiedzy fałszywej lub zmanipulowanej, ale też dlatego, że wiąże naukę z takim obszarem mediów, który nie jest wiarygodny ani nie jest postrzegany jako pożyteczne źródło informacji.

- Dyskurs wojujacy ma na celu zaprzeczenie wartości wiedzy naukowej, podważanie wiarygodności konkretnych badań lub propagowanie wiedzy fałszywej w celu wywołania konkretnych, praktycznych zmian w zachowaniach jednostek i rozwiązaniach społecznych lub politycznych, bądź też uzyskania społecznego poparcia dla już odbywających się działań tego typu. 
Na tle tych dyskursów rozwijają swoją komunikację jednostki, grupy, organizacje jawnie antynaukowe.

\section{Próba i metodologia}

Podstawowe pytanie badawcze brzmiało zatem: jakich ram konceptualnych i interpretacyjnych dla pojęcia nauki używają w komunikacji interaktywnej jednostki i grupy otwarcie walczące ze społecznie legitymizowaną wersją racjonalnej wiedzy naukowej?

Spośród licznych kanałów i narzędzi komunikacyjnych, którymi się posługują, wybrano polskie strony internetowe o jawnym, otwarcie zdefiniowanym celu i charakterze antynaukowym. Przeanalizowana została komunikacja na stronach trzech ruchów antynaukowych i antyracjonalnych sprzeciwiających się oficjalnemu stanowisku nauki w obszarze medycyny, fizyki i historii. Wcześniej, w celu wstępnego określenia cech i charakterystyki materiału, poddano oglądowi publikacje większej liczby grup o pokrewnym charakterze działających w sieci. Lektura tych dodatkowych materiałów miała na celu upewnienie się, że - przy odmiennej tematyce - nie zawierają one konceptualizacji wiedzy w sposób wyraźny odmiennych od tych, które występowały w trzech badanych obszarach tematycznych. Wstępna lektura wykazała względną jednolitość ramowania wiedzy i nauki w całym obszarze komunikacji ,,antynaukowej”.

Do analizy wybrano trzy zróżnicowane obszary tematyczne.

1/ Komunikacja w internecie dotycząca oporu przeciwko przeprowadzaniu szczepień ochronnych (zatem podważająca wiarygodność wiedzy medycznej i biologicznej). Materiał do badań pobrano z największej polskiej strony internetowej poświęconej temu zagadnieniu o nazwie Ogólnopolskie Stowarzyszenie Wiedzy o Szczepieniach „STOP NOP” (w dalszym ciągu wszystkie cytaty z tego portalu są oznaczone identyfikatorem NOP), z sekcji poświęconej szczepieniom w agregatorze publikacji na temat ,alternatywnej” nauki Polski Portal Informacyjny Robert Brzoza, wraz z komentarzami i dyskusją - podstrona Inne Spojrzenie (identyfikator MB) oraz z tematycznego wątku ,szczepieniowego” w Forum Dyskusyjnym Płaska Ziemia (FPZ). Jako kontekst i grupa kontrolna posłużyła komunikacja przeciwników leczenia kanałowego oraz zwolenników tez o szkodliwości śladów pozostawianych przez samoloty odrzutowe (chemtrails), oraz strony internetowe zwolenników alternatywnych terapii i diet.

2/ Komunikacja zwolenników tezy o płaskości Ziemi (zatem podważająca ustalenia fizyki, matematyki, astronomii). Materiał do badań pobrano z forum dyskusyjnego Forum Płaska Ziemia (FPZ), portalu internetowego Zbawienie.pl (ZBA) oraz ze stron internetowych związanych z Polskim Stowarzyszeniem Badaczy Płaskiej Ziemi: Płaska Ziemia, Nowy Porządek Świata \& Więcej (PZ) i Polskie Stowarzyszenie Badaczy Płaskiej Ziemi (SPZ). Jako kontekst posłużyły media zwolenników kreacjonizmu i alternatywnych wersji archeologii i paleontologii.

3/ Komunikacja proponentów teorii o pochodzeniu Polaków od starożytnego plemienia Lechitów oraz o historycznych korzeniach Polski w państwie Lechitów - tzw. Wielkiej Lechii (zatem podważająca oficjalną wiedzę historyczną). Kontekstem były media internetowe poświęcone innym, ,alternatywnym”, wersjom historii Polski. Materiał pobrano ze strony Polski Portal Informacyjny Robert Brzoza - zakładka SuperFakty.info/Historia (RB), portalu Słowianie i Ukryta Historia Polski (SLO) oraz forum dyskusyjnego Niezależne Forum - Cheops. Forum dla WSZYSTKICH! - zakładka WIELKA LECHIA, HISTORIA I PRZYSZŁOŚĆ!!! (CH). 
Z opisanych trzech obszarów tematycznych pozyskano - losowo, metodą kuli śnieżnej - po 120 postów lub akapitów. Jednostką rejestracji uczyniono akapit, nie zaś całą publikację, często bowiem w jednym tekście występują różne tematy, i nie wszystkie akapity zawierają konceptualizację nauki i wiedzy naukowej. Warunkiem zaliczenia do próby była zgodność z kryteriami operacjonalizacji: wybierano takie wypowiedzi, które w sposób jawny odnosiły się lub odwoływały do nauki, wiedzy naukowej, naukowców (także tych zidentyfikowanych z imienia i nazwiska), a także procesów poznawczych i procedur związanych z nowoczesną nauką w rozumieniu racjonalnym (zawierały zatem takie wyrażenia, jak dowodzenie, badanie, wnioskowanie, teoria, eksperyment, analiza itp.; naukowiec, badacz, ekspert, specjalista, nauczyciel; edukacja, wykształcenie, wiedza; uniwersytet, laboratorium, ośrodek badaczy, szkoła itp.).

Próbę gromadzono skokowo, losując korpusy cząstkowe po 30 akapitów. Wybierano je z publikacji awizowanych odrębnym tytułem na tzw. pierwszej szybie wraz z ich - ewentualnym rozwinięciem pierwszego stopnia (zatem po pierwszym kliknięciu, lecz bez dodatkowych leksji wzbogacających materiał lub łączących go z innymi tekstami). Założono, że gromadzenie akapitów zostanie zatrzymane, gdy próby będą wykazywać nasycenie, tj. gdy w każdym z trzech korpusów źródłowych zaczną się powtarzać w sposób konsekwentny takie same argumenty, nie będzie już natomiast w nich wątków, rozwiązań i treści nowych. Wyraźnym wskaźnikiem wysycenia próby stało się powtarzanie się $\mathrm{w}$ różnych miejscach dokładnie tych samych publikacji - strony i fora poświęcone tematyce antynaukowej cytują się i nawiązują do siebie wzajemnie.

Ostatecznie zatem analizie ramowania poddano 360 akapitów/postów. Analizowano dobór słów, retorykę, nawiązania intertekstualne oraz umiejscowienie badanych wypowiedzi w medialnym dyskursie, szczególnie w kontekście dyskursów paranaukowego, antynaukowego, retorycznego i wojującego. Prosta analiza ilościowa doprowadziła do identyfikacji konceptualizacji przeważających w trzech korpusach tematycznych. Wykorzystano narzędzia framing analysis, ponieważ „schematy interpretacyjne, osadzone w dyskursie medialnym za pomocą określonych słów, metafor, obrazów i innych sposobów prezentacji, użytych przez różnych aktorów społecznych" (Franczak, 2014, s. 145) mają trzy funkcje, których zrozumienie jest ważne, gdy próbujemy wytłumaczyć mechanizmy rozprzestrzeniania się postaw antyracjonalnych. Primo, są narzędziami myślenia - dostarczają zrozumiałych wytłumaczeń, przekonujących metafor i emocjonalnie skutecznych ujęć rzeczywistości; ich analiza pozwala więc na wgląd w sposób rozumienia świata komunikujących się podmiotów. Secundo, stosującym je podmiotom umożliwiają proces selektywnej kontroli nad zawartością komunikacji: generowania pożądanych interpretacji zjawisk i wydarzeń albo wzmacniania interpretacji już istniejących, wykluczania lub unieważniania interpretacji niepożądanych z punktu widzenia nadawcy. Tertio - pomagają zrozumieć skuteczność perswazyjną komunikowania.

Wybrane teksty poddano także mikroanalizom jakościowym nakierowanym na pogłębiony opis charakteru zawartych w nich konceptualizacji wiedzy i racjonalności. Analizowano też ilustracje, zostaną one jednak opisane w odrębnym opracowaniu. Za istotne uznano zwłaszcza takie sytuacje, w których komunikowanie wizualne nie stanowi rozwinięcia, wzmocnienia czy kontynuacji wypowiedzi zwerbalizowanych, lecz samo w sobie pełni funkcję modusu wiodącego; przejście od cywilizacji słowa do kultury obrazu jest bowiem jednym z istotnych komponentów zwrotu antyracjonalnego w komunikowaniu.

\section{Ramowanie nowoczesnej wiedzy naukowej}

W rezultacie analizy potwierdzono, że stosunek do nauki, wiedzy naukowej i opartego na nich racjonalnego działania wyrażał się $\mathrm{w}$ tych dyskursach $\mathrm{w}$ ramowaniu nauki w opisane poniżej sposoby, ujęte tu w postaci zdań postulatywnych. 
I. Nie należy wierzyć oficjalnej nauce.

W obrębie „opowieści” o bezwartościowości lub szkodliwości wiedzy naukowej można wyróżnić kilka powtarzających się ujęć.

- Niewiarygodność racjonalnej wiedzy naukowej jako takiej.

(PZ) W prawdziwej nauce chodzi o Jednostki, to od nich się wywodzi, tak że jednostki eksplorują rzeczywistość $i$ w miarę upływu czasu dowiadują się co to właściwie jest, a nie zestaw z góry przyjętych pomysłów albo poszczególnie kupowanych religijnych wierzeń, które chcą aby były prawdą ${ }^{1}$.

(SBPZ) To co należy ustalić na początku, to zgoda co do tego że istnieje tylko Jedna Obiektywna Rzeczywistość i nie jest ona pomysłem ani koncepcją, którą można debatować i wygrać bądź przegrać za pomocą retorycznych środków, tylko może być stwierdzona poprzez Praktyczną Demonstrację. Stwierdzanie czegoś za prawdziwe, ale nie posiadanie na to żadnej praktyczności to Pseudonauka.

Dyskurs antynaukowy każe tu odrzucić naukę w ogóle; paranaukowy natomiast, jak widać, usiłuje znaleźć kompromis, definiując warunki, pod jakimi ewentualnie wiedza naukowa mogłaby być akceptowalna. Interesującą cechą takiego ujęcia jest skrajny, naiwny empiryzm. Nie zawsze więc chodzi o bezwarunkowe odrzucenie nauki jako takiej; raczej o kłopot $\mathrm{z}$ akceptacją nauki opartej na teorii, rozumowaniu logicznym, ekstrapolacji itp. Nie wierz niczemu, czego nie możesz zobaczyć na własne oczy, najlepiej dotknąć to i wypróbować - mówią przeciwnicy oficjalnej nauki, mentalnie cofając się do starożytnego modelu naukowego (zakładającego, że „uzasadnianie naukowe może się tylko odwoływać do faktów empirycznych i logicznych (zasady logiczne podane explicite), fizyka ma badać świat jakościowo, a nie ilościowo, bazując na doświadczeniu potocznym; dopuszczalne jest wyjaśnianie teleologiczne, za pomocą pojęcia „przyczyny celowej” (Tałasiewicz, 1995, s. 96). Antynaukowość może się tu także wiązać z ujęciem antyracjonalizmu jako kwestii osobistej decyzji. Brak zaufania do nauki ma być oznaką krytycznego oglądu świata i niezależności myślowej lub też świadomą realizacją prawa wyboru (mam prawo wierzyć w to, co chcę, nikt/inni ludzie/państwo/instytucje religijne/instytucje naukowe nie mają prawa mnie zmuszać do wiary w naukę lub działania na podstawie wiedzy naukowej).

(FPZ) Mogę stwierdzić że Ziemia jest demonstrowalnie pozioma, a jeśli ktokolwiek chce abym usunął mój zdrowy rozsądek, moje bezpośrednie doświadczenia mojego codziennego życia i zignorował to na rzecz absurdalnego wyobrażenia fantastycznej rzeczy, lepiej żeby miał coś konkretnego do zaoferowania.

(FPZ) Spokojnie, masz prawo mieć swoje przekonania hahahaha....... jestem badaczemnaukowcem-poszukiwaczem, życie czytam miedzy wierszami, o historii wiem tyle, że była pisana przez bandytów, a to co im nie było na rękę wymazywali z kart historii.

(FPZ) Dawniej nie było technologii takiej jak dziś. Może i była, ale nie była dostępna dla ogółu i używając kilku sprytnych sztuczek można nam było wciskać takie rzeczy jak lądowanie na księżycu, planety, gwiazdy, kosmos, ufo, dinozaury... Przez pazerność i chęć zarabiania pieniędzy, technologię udostępnili i każdy dziś nagrywa i umieszcza w internecie wszystko, pojawiają się pytania i ludzie zaczynają się zastanawiać.

${ }^{1}$ Dla ułatwienia lektury ze wszystkich postów usunięto błędy ortograficzne, interpunkcyjne i usterki korektorskie. Zachowano oryginalne stosowanie wielkich liter. 
Wyrazem samodzielności i krytycyzmu ma być także osobiste sprawdzanie i falsyfikacja wyników badań naukowych - często za pomocą metod „zdroworozsądkowych” i „oczywistych”.

(FPZ) Jeśli ziemia na prawdę jest płaska, dlaczego nie sprawdzić tego w praktyce? Wybrać najdalej położony na zewnątrz ląd, zorganizować tam bazę z zapasami żywności i sprzętu i wyruszyć prostopadle na wprost wzdłuż południka. Jeśli ziemia jest okrągła i są satelity, używając elektroniki bez problemu powinniśmy opłynąć lub oblecieć ziemię dookoła i wrócić na start. Jeśli żyjemy na płaskiej ziemi, pod kopułą, prędzej czy później do niej dotrzemy. Jeśli prawdą jest, że ziemia jest płaska a wodę ogranicza gruba warstwa lodu wysoka na $70 \mathrm{~m}$ to powinna ona być wszędzie i zamiast wrócić na start, dotrzemy do niej. Taki dowód na pewno utarłby nosa wszystkim niedowiarkom.

(FPZ) EKSPERYMENT KTÓRY SAMI MOŻEMY ZROBIĆ. Jak UDOWODNIĆ, że Kosmicznakula Ziemia się kręci. 1. Weź dowolny balon wypełniony helem i przymocuj sznurek obciążonym końcem (z wystarczającą wagą, aby balon nie mógł odlecieć). 2. Następnie umieść balon w samochodzie, zwróć uwagę, że kiedy porusza się pojazd, balon również porusza się w kierunku jazdy. 3. Na koniec wyjmij balon z pojazdu i umieść go na ziemi, zauważ, że balon porusza się w kierunku podróży.

- Alternatywne formy wiedzy i poznania.

Niezależnie od argumentacji empirycystycznej w antynaukowym dyskursie silny jest wątek istnienia alternatywnej ,prawdziwej” wiedzy oraz jej przewagi nad wiedzą naukową.

$(\mathrm{CH})(\ldots)$ symbolem macierzy jest Wielka Matka, której odzwierciedlenie przedstawiane jest w obrazach obecnych we wszystkich kulturach świata. Jednak ta nowatorska zdawałoby się wiedza tak naprawdę wcale nie jest taka nowatorska, ponieważ została ona zaczerpnięta ze starszej wiedzy zwanej Wedą. Weda to po polsku „wiedza”. Oznacza prawdziwe poznanie, nie zaś powstałe w kali-judze - wieku ciemności martwe obyczaje. Skostniałe wierzenia i religie to tarcza ochronna niewiedzy.

(FPZ) Stara mapa Buddyjska oraz wiele dowodów świadczy o tym, że ziemia jest płaska i że obok naszej ziemi znajdują się inne płaskie ziemie. (...) Czy buddyjska mapa jest dla mnie wiarygodna ? Tak! Wiarygodniejsza niż Stała Grawitacyjna i Teoria Względności Einsteina, niż wszystkie fikcyjne fotki i animacje kosmosu prezentowane przez NASA (o lotach na księżyc i stacji ISS nie będę pisał, bo to śmiech na sali).

(MB) Czas na zmiany w polskiej medycynie. Mamy setki przykładów wyleczeń ciężkich chorób przy użyciu naturalnych terapii. Czas, aby to lekarze mogli oficjalnie leczyć nas najskuteczniejszymi metodami, a nie tymi narzuconymi przez system farmaceutyczny.

- Przewaga poznania metafizycznego (wiary, objawień, świętych ksiąg, wróżb i przepowiedni, poznania duchowego itp.) nad naukowym.

Niekiedy jest to kwestia abstrakcyjnie ujmowanej duchowości czy intuicji.

(FPZ) Polecam zachować intelektualną niezależność i nie akceptować jako prawdy każdego słowa pisanego lub mówionego przez kogokolwiek, tylko pozostać krytycznym i sceptycznym i nadal wykorzystywać swoją intuicję i rozeznanie.

(SLO) My Polacy wszystkich czasów i przestrzeni jesteśmy jednym organizmem o licznych powiązaniach zewnętrznych i wewnętrznych. Żyjemy w erze informacji, w okresie przyspieszonych zmian w sferze samoświadomości, Nowej Świadomości i wiedzy. Nie traćmy czasu na pielęgnowanie tego, co już nie jest prawdą naukową. (SLO) 
Częściej jednak zaufanie do nauki będzie ujmowane jako sprzeczne z tradycją, religią, religijnie ugruntowaną moralnością.

(MB) Nic dziwnego, że miliony ludzi dostało raka z wirusa polio - te szczepionki, to nic innego, jak eksperymentalne mikstury krwi zwierzęcej, genetycznie zmodyfikowane wirusy, krew z aborcji i toksyny metali, które powodują zaburzenia centralnego układu nerwowego i zaburzenia autoimmunologiczne. Wprawdzie nie obowiązuje nas Prawo mojżeszowe, ale zakaz spożywania krwi został szczegółowo wyjaśniony (...). Z tego wynika, że żaden człowiek nie powinien spożywać krwi zwierzęcej, a co dopiero ludzkiej.

Takie interpretacje mogą być konstruowane w duchu nostalgicznym (kiedyś było lepiej, kiedyś nie było „takich problemów”, należy szanować tradycję, nie należy za dużo zmieniać, nasi przodkowie znali prawdę, zbiorowość wie najlepiej); fatalistycznym (nauka nie ma znaczenia, ponieważ i tak czeka nas zagłada; rozwój nauki to oznaka nadchodzącej zagłady; Bóg tak chce; koniec świata blisko; wszyscy umrzemy), lub też optymistycznym (nauka nie ma znaczenia, ponieważ Bóg się nami opiekuje, prawda i tak wyjdzie na jaw, zaufajmy Bogu, a nie nauce, to nie stanie się nic złego).

(ZBA) Kto zrobił to zdjęcie? Przecież nie mamy z kosmosu ani jednej fotografii Ziemi! Spójrzmy na to $\mathrm{z}$ perspektywy płaskiej Ziemi. Wygląda ona w przybliżeniu jak na tym rysunku i jest szczelnym systemem zamkniętym. Natychmiast czujemy się lepiej i pada natychmiast pytanie. Kto ten zamknięty system stworzył i dlaczego go zamknął? Odpowiedź jest prosta - Bóg i mamy wiele informacji na ten temat w Biblii.

- „Zdrowy rozsądek” i wiedza potoczna zamiast nauki.

Istotnym wątkiem jest też nadrzędność wiedzy potocznej i tzw. zdrowego rozsądku nad wiedzą naukową.

(MB) Proszę zwrócić uwagę na zakończenie tego artykułu: „Tylko w zeszłym roku na starym kontynencie zachorowało na nia ponad 20 tys. osób, kilkadziesiąt zmarto... Dlatego, że kilkadziesiąt osób zmarło w Europie, politycy wprowadzili przymus szczepień? Wymuszają na nas szczepienia pod groźbą kar finansowych... bo zmarło kilkadziesiąt osób? Za chwilę wprowadzą określone godziny wychodzenia $\mathrm{z}$ domu, bo może wybuchnąć wojna...? Za chwilę wprowadzą zakaz korzystania $\mathrm{z}$ internetu, bo może ktoś włamać się nam do komputera...? Przecież to nie ma sensu...

Odwoływanie się do wiedzy zdroworozsądkowej w sposób pozornie logiczny jest powiązane z opisywanym wyżej empiryzmem naiwnym.

(FPZ) teoria heliocentryczna, dosłownie „lecąc” na przekór bezpośredniej obserwacji, eksperymentalnym dowodom i zdrowemu rozsądku, utrzymuje, że kulista Ziemia obraca się dookoła własnej osi z prędkością 1.000 mil $(1.609 \mathrm{~km})$ na godzinę (...), choć nikt nigdy w historii nic nie poczuł! Możemy poczuć najlżejszą bryzę w letni dzień, ale nigdy na jotę ruchu powietrza w związku z tym niewiarygodnym pędem! (...) Dlaczego czujemy najdelikatniejszy wietrzyk zachodni, a nie czujemy niewiarygodnego rzekomego ruchu o prędkości 1.000 mil $(1.609 \mathrm{~km}) \mathrm{na}$ godzinę na wschód?!

Jest to zjawisko szczególnie niebezpieczne, ponieważ odwoływanie się do wiedzy potocznej jest w istocie szczególną formą racjonalizmu (Tałasiewicz, 1995, s. 83), zaś ,potoczne opinie pozbawione obiektywnego uzasadnienia, a kształtowane przez tradycję, nawyki, uprzedzenia czy powszechną zgodę" (Życiński, 2000, s. 200) często opierają się na rozumowaniu powierzchownie podobnym do empirycystycznie rozumianego poznania naukowego. Co więcej, rozróżnienie pomiędzy kwalifikowaną wiedzą a wiedzą potoczną ma w społeczeństwie informa- 
cyjnym komponentę konfliktu klasowego. Dostęp do edukacji i wiedzy naukowej to element społecznego uprzywilejowania. Wiedza potoczna natomiast, stereotypowo wiązana z życiowym doświadczeniem, ustalana i potwierdzana w relacjach międzyludzkich, ma oddolny, demokratyczny charakter. Jej dezawuowanie bywa więc interpretowane jako przejaw klasowej pogardy i elitaryzmu, a powoływanie się na nią - jako przejaw demokratyzmu i zrozumienia dla ,zwykłego człowieka".

Zamiast zatem ustalać prawdę za pomocą metod naukowych, w komunikacji grup antynaukowych proponuje się jej ustanawianie w sposób roszczeniowy:

(FPZ) My tylko robimy to, co ma sens. Mówimy, że teoria dotycząca poruszającej się Ziemi nie ma sensu. Teoria o nieruchomej Ziemi ma sens, a jednak nas ośmieszają. Trzeba wyobrazić sobie sytuację odwrotną, by dostrzec jaka jest śmieszna.

(SLO) Na początek ta wiedza nie musi być na poziomie uniwersyteckim, wystarczą podstawowe informacje, ale $\mathrm{z}$ wielu dziedzin.

lub społecznościowy, oparty na „powszechnej” zgodzie:

(RB) Masowe wymazywanie polskiej historii miało miejsce dopiero pod zaborami. Do tego czasu każdy Polak wiedział, że jest Lechitą, Sarmatą, potomkiem bogów czy Panem (do dziś tytułujemy się per Pan, Pani, a zbiór Polaków nazywamy „państwem”) i wszystkie polskie kroniki to potwierdzają. W zasadzie to nie tylko polskie, bo zachodnie również.

(ZBA) Gdyby heliocentryzm i ziemia kula były bezspornym faktem, mielibyśmy kilka audycji TV w których widzielibyśmy na żywo obracającą się Ziemię wprost z Hubble teleskopu! Pokazywano by nam olbrzymie zbliżenia na ziemi a my widzielibyśmy ruch pojazdów czy start samolotów na lotnisku. Moglibyśmy pomachać rękami a Hubble by to zarejestrował. W jednym dniu ustałyby jakiekolwiek spekulacje na temat płaskiej ziemi a inicjatorzy tego pomysłu rumieniliby się ze wstydu.

Stosowana jest też heurystyka dostępności (Tversky \& Kahnemann, 1973) oparta na przewadze nad nauką wiedzy anegdotycznej, opartej na własnym doświadczeniu,

(NOP) Kolejne dziecko z odrą. Nie zostało zarażone przez osobę nieszczepioną a przez szczepionkę, którą miało podaną. Jej mama wynajęła laboratorium, żeby potwierdzić że wirus odry którym zostało zarażone jej dziecko to wirus odszczepienny...

(ZBA) Jak sprawdzić czy te satelity są na orbitach? Wziąć dobrą lornetkę lub teleskop i oglądać Księżyc. Powinniśmy na jego tle widzieć co najmniej 500 satelitów w ciągu 12 minut obserwacji. Te które są bliżej ziemi - nie wszystkie są odległe w tysiącach kilometrów powinny być widoczne nawet w zwykłej lornetce. Poszukiwania na Google dają nam jedynie i rzadko zdjęcia księżyca z ISS na jego tle, co jest żartem zrobionym przez kogoś dla zabawy. Nie znalazłem zdjęcia żadnego satelity na tle księżyca. A powinny ich być setki! Gdyby satelity istniały, mielibyśmy tysiące dowodów w postaci zdjęć satelitów na tle księżyca czy zachodzącego słońca.

niekiedy zaś po prostu przysłów, przesądów, baśni i legend, fikcji literackiej.

(RB) Daleko nie trzeba szukać analogii. Każdy kto oglądał „Grę o tron”, wie w jaki sposób pisze się o „barbarzyńcach zza muru”, my z punktu widzenia Grecji i Rzymu byliśmy właśnie takimi barbarzyńcami, a Dunaj i Łaba/Ren były takim murem.

Ciekawe, że dezawuowanie nauki i metod naukowych łączy się z zapewnieniami o naukowym właśnie potwierdzaniu promowanych koncepcji antynaukowych. Autorzy wypowiedzi albo zdają sobie sprawę, że pełne podważanie paradygmatu naukowego jako takiego obniża perswazyjną 
wartość wypowiedzi, albo też zinternalizowali prawomocność nauki tak dalece, że nie są się w stanie od tej postawy oderwać. Pomimo negatywnego stosunku do nowoczesnej nauki, używają jej więc do uwiarygodnienia własnych celów

(NOP) Szczepionki przyczyną ,epidemii” odry? Dowody naukowe.

(RB) Stara nazwa Polski - to Lechia !!! Są mocne dowody na to, naukowcy to potwierdzają.

II. Nie należy wierzyć niektórym teoriom i wynikom wybranych badań naukowych.

Tu także powtarza się kilka stałych wątków.

- a/ Bezwartościowość, brak wiarygodności wybranych teorii naukowych.

(FPZ) Teoria Kwantowa to badania atomów i subatomów. Fantastyka Naukowa sprzedawana na poziomie Uniwersyteckim jako Fizyka Teoretyczna. Praca Einsteina jest również znana ze swojego wpływu na filozofię nauki. Filozofia Nauki ustala podstawy, metody i konsekwencje nauki; przez określenie tego, co kwalifikuje się jako nauka, teorie naukowe i ostateczny cel nauki. Innymi słowy, filozofia nauki pozwala Fantastyce Naukowej wejść do systemu edukacyjnego pod pozorem TEORII.

(SPZ) Heliocentryczny model kuli jest koncepcją. Istnieje tylko w umysłach myślicieli $\mathrm{z}$ abstrakcyjnymi złudzeniami.

- b/ Niemożność osiągnięcia jednoznacznych rezultatów badań naukowych i empirycznego potwierdzenia teorii.

(ZBA) Dzisiejsze obliczenia promienia Ziemi traktuje się i oblicza w identyczny sposób, zakładając zupełnie bezpodstawnie, że Ziemia jest kulą. Dlatego błędnie, ponieważ nie mamy ani jednego dowodu na jej kulistość. Nie posiadamy także ani jednego wiarygodnego zdjęcia z kosmosu Ziemi jako kuli, a przyczyny są oczywiste. Podróże w przestrzeń kosmiczną są niemożliwe z wielu przyczyn.

- c/ Niewłaściwa interpretacja wyników badań naukowych przez środowiska naukowe i decydentów.

(SLO) Organizm państwowy Słowian Europejskich, nazywany czasami Wielką Lechią, bądź też Imperium Lechitów jest dla naszych naukowców trudny do zauważenia, ponieważ szukają oni czegoś innego niż to, czym Lechia była. Nie rozumieją ani gospodarki, ani polityki, ani wojskowości, ani psychologii i socjologii Narodów i Ludów Imperium Lechitów. Problem jest jeszcze głębszy, bo często nie rozumieją oni nawet historii Polski.

(NOP) Na Ukrainie zachorowania wzrosły wraz z masową kampanią szczepień.

- $\quad \mathrm{d} /$ Celowe fałszerstwa, ukrywanie prawdziwych wyników badań naukowych w wyniku złej woli lub spisku.

(NOP) Wyniki ankiety o NOP - 2000 przypadków i 20 śmierci pominięte w rządowych statystykach.

(SLO) W ciągu ostatnich 300 lat nauka światowa i polska, pod wpływem przeważającej ,naukowej” propagandy niemieckiej i Zachodniej, w sposób świadomy i zorganizowany zmieniła zupełnie obraz świata Słowian, a szczególnie Polaków.

(ZBA) Co jest celem takich mega kłamstw? Cóż się ukrywa przed nami? Dlaczego ziemia kula i system heliocentryczny są tak ważne dla władz, że one zmuszają nas do uwierzenia $w$ ten stek kłamstw i bzdur? Staje się oczywiste, że za pomocą tego kłamstwa rządy z ONZ włącznie 
kontrolują skutecznie populację całej ziemi. (...) Kłamie się w szkołach, w mediach, z pulpitów pastorskich czy z ambon kościelnych i zawsze kłamcami są ci, którzy nas kontrolują właśnie za pomocą kłamstw.

III. Nie należy wierzyć naukowcom.

Licząc się zapewne $\mathrm{z}$ potencjałem perswazyjnym postaci naukowca, autorzy wypowiedzi antynaukowych posługują się często autorytetem naukowców - fikcyjnych lub prawdziwych.

(NOP) Ekspert A, światowej sławy neurolog dziecięcy, został zapytany pod przysięgą: „Czy renomowani lekarze w Twojej branży zgadzają się, że szczepionki powodują rodzaj reakcji zapalnej, która może prowadzić do regresywnego autyzmu?” Odpowiedział: „Tak”.

(MB) Po niezależnym zbadaniu literatury medycznej o szczepieniach, dr Viera Scheibner stwierdziła, że...; W grudniu 1994 r. w Medical Post, Dr Guylaine Lanctot autorka bestsellera „Medical Mafia”, powiedziała...; Dr Boyd Haley, przewodniczący Wydziału Chemii na Uniwersytecie Kentucky, jeden z wiodących ekspertów w kwestii zatruć rtęcią powiedział...; Niemieckie badania stwierdziły...

(FPZ) Co bardziej śmieszy, to fakt, że nawet człowiek jak Steven Hawking i kilku intelektualnie uczciwych fizyków i kosmologów, którzy przeczytawszy to co tu piszemy byliby w stanie to zrozumieć, wiedzą, że to co piszemy jest całkowicie prawdziwe.

Generalnie jednak wizerunek naukowca jest zdecydowanie czarny. Tu także powraca kilka motywów.

- Nieudolność i ignorancja naukowców i edukatorów.

(CH) W sposób oczywisty historycy muszą się mylić, nasza historia jest znana, tylko oni nie potrafią jej odczytać z tysięcy różnych kwantów informacji i całych fragmentów tekstów, które dotarły do nas z starożytności, informacji mówiących nie tylko o naszej historii, ale o równie wysoko rozwiniętej cywilizacji co grecka czy rzymska.

- Dwuznaczny status moralny i etyczny naukowców, zwłaszcza korupcja:

(MB) Przemysł farmaceutyczny dysponuje niewyobrażalnie wielkimi sumami, które przeznacza m.in. na kontrolę badań, narzucanie swoich norm organizacjom takim jak: WHO lub SANEPID, korumpowanie lekarzy, polityków, opłacanie spotów medialnych, newsów itp.

(SLO) Byli to, i nadal niestety są, antypolscy historycy, archeologowie, publicyści i propagandziści będący pod wpływem obcych ośrodków wyspecjalizowanych w sianiu antypolskiej propagandy.

tchórzostwo i konformizm:

(MB) (...) medycyna jest dziedziną, która wymaga zgodności, gdzie jest niewielka tolerancja na poglądy przeciwne statusowi quo. Lekarze nie mogą cię ostrzec o tym, o czym oni sami nie wiedzą a z niewielkim czasem do dalszej edukacji po rozpoczęciu praktyki, są w pewnym sensie, przetrzymywani przez system, który zniechęca ich do pozyskiwania niezależnych informacji i tworzenia własnych opinii.

oraz cynizm i amoralność:

(ZBA) Teoria względności to także fałsz i dlatego nie wspiera on grawitacji. Tesla miał 660 patentów, a plagiator Einstein miał ich... zero, czyli był naukowym oszustem i zerem.

(MB) Szczepionka testowana na... dzieciach (...) W drugim etapie szczepionka będzie badana u... dzieci, a jej celem jest zbadanie zarówno bezpieczeństwa szczepionki, jak i jej skuteczności przeciw enterowirusom. 
(RB) To, co mówią profesorowie z Niemiec (Brückner, Godłowski i inni), jest niestety przesiąknięte tego typu dogmatami i jednostronnością. Nie możemy polegać na sądach profesorów - ani z Zachodu, ani ze Wschodu.

(ZBA) Jakie przyczyny kierują kłamcami w tej dziedzinie? Identyczne, jakie kierują przy stawianiu hipotezy pra wybuchu czyli teorii magicznej kropeczki, teorii ewolucji, teorii względności oraz teorii heliocentrycznej. Cele są dwa. Pierwszym celem jest zabić w twoim umyśle możliwość, że Bóg istnieje. Drugim celem jest zniszczenie rodzaju ludzkiego

- Spisek środowisk naukowych lub naukowców i polityków, celowo ukrywających prawdę.

(MB) Gdyby szczepionki na grypę były bezpieczne, gwarantowałyby zdrowie, to czy lekarze nie korzystaliby z takiego dobrodziejstwa?

(RB) Problem w tym, że to nazbyt pochlebna dla Polaków wiedza, a poniżająca Niemców. Mówią o tym kroniki biskupa Kadłubka, Dzierzby, Długosza, ruskiego kronikarza Nestora i innych. Podważa się ich wiarygodność tak jak obozy koncentracyjne niemieckie (co najwyżej faszystowskie) wtłaczając w historię, że były polskie.

(ZBA) Faktem jest to, że Ziemi kuli nie broni żaden naukowiec, żaden profesor astronomii, żadne ciało naukowe, żadne poważne forum naukowe a mas media ogólnie milczą w cichej nadziei, że temat się w końcu znudzi i odejdzie na bok. Podejrzani zachowują się dokładnie tak jak osoby podejrzane.

- Elitaryzm środowiska naukowego i brak zainteresowania naukowców potrzebami i dobrem „zwykłego człowieka”.

(MB) „Procent zaszczepionych pracowników służby zdrowia jest w granicach ok. 6 proc. Uważam to za rzecz skandaliczną" - tak mówi profesor Lidia Brydak w 2014 roku. Czyżby tylko 6,4 procent pracowników służby zdrowia szczepiło się na grypę? Czyli lekarze, pielęgniarki, technicy i inni pracownicy nie chcą szczepić się! Dlaczego, skoro nawet minister zdrowia publicznie wstrzyknął sobie szczepionkę? To są ładne kwiatki, jak mówi pani profesor. Jeżeli nawet lekarze nie chcą szczepić się, to dlaczego jest taka nagonka na rodziców?

\section{Nie należy wierzyć instytucjom naukowym i edukacyjnym.}

- Korupcja instytucji.

Nieufność w stosunku do instytucji opiera się na tezach o korupcji, nieudolności i cynizmie ośrodków naukowych; uczelnie i szkoły ujmowane są najczęściej w kontekście współdziałania z politykami, mediami, kościołem, wielkim biznesem. Nieufność do zinstytucjonalizowanej nauki wpisuje się więc w ogólną, widoczną w mediach narrację o braku zaufania do instytucji nowoczesnego państwa.

(FPZ) Natomiast oficjalne twierdzenia nauki odnośnie świata w którym żyjemy są w znacznej mierze fantazją promowaną przez media i sprzedawaną poprzez uniwersytety pod pozorem Nauczania Akademickiego (Udawanego).

(RB) Mam nadzieję, że już każdy teraz wie, skąd się wzięła "Historia" w polskich szkołach. Zapraszam do polskich kronik oraz słowników.

(FPZ) w szkole uczyli, że tak jest więc ślepo wkuwało się wszystko, żeby oceny były dobre.

- Potrzeba alternatywnych instytucji.

Wynika z tego potrzeba zbudowania „nowego” środowiska naukowego. 
(RB) Musimy się dorobić pokolenia własnych profesorów nieskażonych dogmatami materializmu marksistowskiego i chrystianocentryzmu, a także wschodnim nie zachodnim oglądem świata. To bardzo trudne, lecz mam nadzieję, że wykonalne.

(SLO) Dopóki nie zostaną założone interdyscyplinarne placówki badawcze, naukowe i edukacyjne, czyli Uniwersytety Słowiańskie i Polskie, my Polacy chcący poznać przeszłość naszego Narodu zmuszeni jesteśmy do prowadzenia indywidualnie pracy od podstaw. Na szczęście podstawową pracę wykonuje już kilku bardzo kompetentnych badaczy, którzy są powszechnie znanymi autorytetami w środowisku oraz szersze grono wspomagających ich fascynatów. A w zasadzie powinienem napisać „kilkoro badaczy”, bo panie też są aktywne.

- Potrzeba działań praktycznych.

Podkreśla się też konieczność radykalnych działań; uruchamia się zatem naukowy dyskurs wojujący.

(MB) Kiedy ludzie dowiadują się, że ojciec, matka, żona, mąż, dziecko, umarli tylko przez szczepionkę lub inny śmiercionośny lek firm farmaceutycznych, to po trupach dotrą do prawdy. Żaden profesorek nie stanie im na drodze.

(MB) Proszę zwrócić uwagę na wściekłość rodziców. Kiedy zabiorą ci dom, pieniądze, kiedy twoje dziecko umrze lub zostanie upośledzone tylko dlatego, że lekarze, politycy nie zatrzymali procesu korupcyjnego, to nie masz nic do stracenia. Walczysz, mówisz prawdę, nie boisz się konsekwencji, zastraszania. Nie zważasz na mądre twarze profesorów medycyny, którzy bez empatii bronią firm farmaceutycznych. Ośmieszasz ich argumentacją, niezależnymi badaniami.

(NOP) Zdecydowanie polecam rodzinom dotkniętych autyzmem, nie zamykać się w domu. Należy łączyć się w grupy i działać większymi siłami. Wpływać na lekarzy, naukowców, polityków. To się musi w końcu zmienić.

(NOP) Ostrzegamy, że od 1 lipca 2019 r. będziemy zbierać i analizować każdy materiał z mediów tradycyjnych i internetowych, gdzie fałszywie nazwano nas antyszczepionkowcami w celu możliwego wytoczenia pozwu przeciw autorowi.

Wezwania do działania, do tworzenia własnego środowiska naukowego oraz do osobistego sprawdzania wiedzy tworzą razem wizję swoistego alternatywnego obiegu wiedzy. Prawdziwa wiedza (a nie oficjalna wiedza naukowa) ma być tworzona przez prawdziwych naukowców (a nie tych skorumpowanych lub nieudolnych), tworzących prawdziwe instytucje dla prawdziwej nauki (nie zaś obecne skorumpowane szkoły i uniwersytety). Z braku alternatywnych instytucji, i przy niewielkiej liczebności alternatywnych badaczy, wytwarzaniem i rozpowszechnianiem prawdziwej wiedzy miałby się zająć swoisty ruch oddolny, złożony z krytycznych, zaangażowanych naukowców - amatorów. Stąd między innymi bardzo liczne porady, jak samodzielnie przeprowadzać eksperymenty „naukowe”, osobiste narracje o przeprowadzonych "badaniach", wezwania do lektury właściwych źródeł oraz do utrzymywania postawy zdrowego krytycyzmu.

(FPZ) Powodem dlaczego dają nam tych fałszywych ludzi na pierwszym froncie, jest to abyśmy nie trafili na autentycznych ludzi będących prawdziwym ruchem oddolnym, tylko trafili na tych podstawionych, których nazywam strażnikami bramy, gdzie prowadzą nas tylko tam gdzie możemy dotrzeć, aby na końcu wpuścić nas w ślepą uliczkę.

W sposób paradoksalny wpisuje się to w etos kultury partycypacji i kolektywnego wytwarzania wiedzy, dla którego podstawą stały się w ostatnich dziesięcioleciach media interaktywne. 
- Destrukcyjna rola mediów.

Jednocześnie zaś mocno podkreślana jest destrukcyjna rola mediów oszukujących ludzi poprzez narzucanie im wiedzy naukowej i dezawuowanie innych form zdobywania wiedzy (wersja antynaukowa) lub przez promowanie wiedzy pochodzącej z badań, ale niesprawdzonych, skorumpowanych, zmanipulowanych, dezawuowanie zaś badań alternatywnych (wersja paranaukowa).

(MB) (...) twórczyni tej szczepionki, Dr Diana Harper, profesor na Uniwersytecie w Missouri Kansas City School of Medicine, przyznała, że nigdy nie badała związku szczepionki z rakiem szyjki macicy i jest to wymysł prasowy.

(FPZ) Powiem tak... Każdy, ale to każdy bez wyjątku, kto długo siedzi w Mediach, ryje nam berety.

(SLO) Ostatnio stan ten stara się zmienić antypolska, obcokapitałowa, ale polskojęzyczna propaganda, która tubami takich mediów, jak GW, Newsweek, Radio TOK FM itp. wmawia nam, że mamy wybór tylko między agenturalnymi partiami typu PO i PIS. I skłócają nas coraz bardziej. Wmawiają nam też, że I Rzeczypospolita była zła, a Wielka Lechia w ogóle nie istniała.

(FPZ) Przez ponad 500 lat, przy pomocy wszelkich metod, od książek, gazet i telewizji, do komputerowo wygenerowanych obrazków, spisek międzypokoleniowy zdołał w umysłach mas poderwać niewzruszoną Ziemię, ukształtować ją w kulę, wprawić w ruch obrotowy i rzucić dookoła Słońca! (...) Stworzona iluzja przebiegle przekonująca, doprowadziła światową populację do wiary w szkodliwy mit.

\section{Styl, retoryka, metaforyka wypowiedzi antynaukowych}

Analiza ujęć językowych i stylu tych wypowiedzi pozwala na wyróżnienie w badanym materiale czterech wyraźnych stylistyk. Każda z nich może służyć do konstruowania każdej z opisanych wcześniej ram interpretacyjnych nauki.

- Stylistyka quasi-naukowa ma powierzchowne cechy strukturalne i słownictwo stylu naukowego.

(NOP) Do analizy tej próbki zastosowano metodę spektrometrii masowej do badania zanieczyszczeń w złożonych matrycach.

(RB)To ja dorzucę jeszcze coś ze swojego ogródka, jakim jest językoznawstwo. Czy wiedzieliście, że na terenie Polski prawdopodobnie mówiono językiem praindoeuropejskim (czyli tak naprawdę prasłowiańskim)?

(RB) Mało tego, okazało się bowiem, że Polacy, Lechici, Wandale zamieszkują swoją ziemię już od ponad 10 tys. lat i posiadają inną podhaplogrupę, niż reszta Słowian - Y-DNA R1a1a7.

Używa się tu terminologii naukowej, w warstwie wizualnej zaś wykorzystuje ikonografię i konwencje reprezentacyjne charakterystyczne dla reprezentacji wiedzy naukowej lub dla materiałów edukacyjnych (mapy, wykresy, archiwalia). Stosowane są formuły narracyjne o charakterze kategorialnym lub analitycznym. Słownictwo i ikonografia reprezentują hierarchiczny model przepływu wiedzy; odnoszą się do władzy i kompetencji naukowców i instytucji edukacyjnych; wiążą wiedzę ze statusem społecznym, autorytetem, doświadczeniem, tradycją. Paradoksalnie, taką stylistykę stosuje się zarówno w celach dezawuowania nauki, jak przy okazji retorycznych wezwań do zmiany sposobu myślenia lub przebudowy społeczeństwa.

- Stylistyke populistyczna charakteryzuje kolokwialność i emocjonalność języka. Charakterystyczna jest inkluzywność języka oraz odwołania - werbalne i za pomocą środków wizualnych - do wspólnotowości, współpracy, jednoczenia się, wspólnej walki. Dobór tematyki 
akcentuje bądź to aspekty emocjonalne reprezentowanych zjawisk i problemów, bądź skandal i sensację, albo też spisek i tajemnicę.

(ZBA) Drogi czytelniku - płaska ziemia to nie strata czasu. Nie musisz niczego studiować i z nikim walczyć. Sprawdź osobiście jeden czynnik i jeżeli to wykluczy heliocentryzm, znalazłeś jedyną logiczną odpowiedź. Heliocentryzm jest kłamstwem! Problem polega na tym, że jeżeli ziemia jest płaska, to WSZYSTKIE władze są naszym wrogiem i powinny być rozwiązane ponieważ ci kłamcy dążą do naszego fizycznego zniszczenia.

W skrajnych wypadkach bywa używana charakterystyczna dla mediów sensacyjnych i tabloidowych stylistyka melodoksyjna (Mrozowski, 2001, s. 232).

(NOP) Będziemy rozmawiali o tym, co tak naprawdę jest w szczepionkach. Jak mówi Jaro, zdejmiemy gacie polskim „ekspertom” o ile będą mieli odwagę przyjść i skonfrontować swoje mądrości z prawdziwą Evidence Based Medicine... - zaprasza na posiedzenie na swojej facebookowej stronie poseł Paweł Skutecki.

(MB) Miliony dzieci uczestniczą w ogromnym, grubaśnym eksperymencie i żadne szczere czy zorganizowane wysiłki nie są podejmowane przez środowisko medyczne aby śledzić negatywne skutki uboczne lub określić długoterminowe konsekwencje...

Język i ikonografia odnoszą się do życia codziennego lub wykorzystują praktyki reprezentacyjne charakterystyczne dla medialnych reprezentacji prywatności, emocji, relacji itp. Częste są odwołania do anegdot, wspomnień, osobistych historii ludzi, a także do tekstów literackich, filmów, rozrywki.

(SLO) A na koniec, trochę anegdotycznie, podam jeszcze opis zachowania Polaków według Andrzeja Sapkowskiego. Sapkowski nie pisał o Polakach dobrze i jakby się za nich wstydził, ale... Ale musiał pewną rzecz przyznać i chodzi tu o to, że Polacy Wspólnotowość i Zgodliwość mają po prostu we krwi. (...) I to jest ta wartość, której inne narody mogą nam zazdrościć i którą nawet tak antypolsko nastawiony pisarz, jak Sapkowski musiał zauważyć (...) jako bystry obserwator rzeczywistości napisał prawdę, a ta prawda, to fakt, że Polacy we Krwi mają dążenie do dyskusji i Zgody. Że nasze poczucie Wspólnoty jest silniejsze, niż różnice zdań, które tak naprawdę nie są wcale takie złe i mogą prowadzić do nowych rozwiązań. W innych krajach wygląda to zupełnie inaczej.

Retoryka jest hiperboliczna.

(MB) Niestety, ale osoby, które powinny stać na straży zdrowia człowieka, sprzeniewierzyli się przysiędze Hipokratesa. Poddali się całkowicie firmom medycznym, które sieją żniwo chorób i śmierci.

(MB) Dlaczego Lechia? Nie chodzi tu o zabawę intelektualną, ale o przeżycie Naszego Narodu.

(MB) ...STOP-NOP (Ogólnopolskie Stowarzyszenie Wiedzy o Szczepionkach) gdzie prowadzona jest kampania informacyjna, której celem jest zaprzestanie otruwania naszych dzieci pod przykrywką rzekomego zwiększania ich bezpieczeństwa. (MB)

Metaforyka i narracje (zwykle w formule fabularnej lub argumentacyjnej) (por. Bordwell \& Thompson 2010, s. 84-126, 388-442) są konstruowane na bazie wyrazistych opozycji binarnych natura-nauka, prywatne-publiczne, elita-zwykły człowiek. Charakterystyczne jest używanie bezpośredniego zaadresowania oraz retoryczne, bezpośrednie lub pośrednie wezwania do działania. 
(FPZ) Jak już wiesz że wszystko co Ci powiedziano jako dziecku, czym karmiono Cię z mediów, jak już wiesz że to było niewłaściwe i znasz już prawdziwe dowody, które są w całości twoimi zmysłami, które przez cały czas Ci mówiły prawdę, to jak już wrócisz do tego, to odzyskasz swoją moc, swoją zdolność do wiedzenia tego, że woda się nie zakrzywia, że nie wirujesz, że horyzont jest zawsze płaski i wznosi się do poziomu oczu, jak już wiesz to wszystko, to nie możesz ponownie wpaść w tą pułapkę systemu-wierzeń.

(SLO) Bardzo Was proszę, podnoście ten temat, gdzie tylko możecie, bo jest on kluczowy dla naszego przetrwania!

(MB) Jak tak dalej profesorowie medycy będą kłamać, to za niedługo wstyd będzie nosić tytuł profesora. Nie będą się durnowato uśmiechać podczas debaty telewizyjnej, tylko w końcu zaczną mówić i bronić prawdy. Jeżeli tego nie zrobią, to ich społeczeństwo zlinczuje. Kwestia czasu...

- Stylistyka narodowo-patriotyczna jest łatwa do rozpoznania z powodu widocznego wykorzystywania retoryki i ikonografii narodowej oraz odwoływania się do argumentacji patriotycznej, dumy narodowej, przyszłości narodu.

(SLO) Chodzi tutaj o udowodnienie ciągłości genetycznej Naszego Narodu. W świetle najnowszych osiągnięć nauk ścisłych, takich jak genetyka i antropologia fizyczna, a ostatnio również archeologia, podanie takich dowodów wydaje się dość proste.

(SLO) Teraz już chyba widzą Państwo związek między ratowaniem substancji biologicznej Naszego Narodu oraz bogactw naturalnych Naszego Kraju, a potrzebą udowodnienia naszej autochtoniczności i uporządkowania dowodów na istnienie Wielkiej Lechii, świadka naszej wielkiej słowiańskiej przeszłości.

(NOP) Dostrzegamy w tym projekcie dążenie do utworzenia ni mniej, ni więcej, tylko policji sanitarnej. I temu się przeciwstawiamy, stojąc na gruncie tradycyjnego pojmowania wolności, polskiej wolności. Chwała Bogu, jeszcze nie określają do końca ram naszego życia ludzie tacy jak autorzy tego projektu.

W doborze słownictwa i ikonografii używa się tu odwołań do symboliki narodowej, historii narodowej, dumy narodowej, nostalgii, tradycji, wspólnoty z minionymi pokoleniami...

(RB) Czy Lechia to prawdziwa nazwa Polski? Dopóki nie zostanie ta sprawa dokładnie zbadana przez historyków, to w żadnym wypadku nie możemy odrzucić takiej tezy. Poszlaki są, pewne dowody również, teraz potrzebujemy tylko udokumentowanych dowodów, aby nikt nie śmiał podważyć naszych korzeni.

... a także do wspólnego wroga (najczęściej Niemców, Żydów, niekiedy masonerii, wielkiego biznesu).

(RB) Na podstawie tychże badań naukowców zachodnich okazało się, że Polska posiada przeszło 10700 lat egzystencji w rejonach Wisły, Zbrucza i Dźwiny. Często mówią o Polakach w złym tonie, w złym guście. Jednak historia pokazuje naszą odwagę, chęć pomocy drugim. To są niesamowite, szlachetne cechy pokazane w bardzo trudnych warunkach, kiedy śmierć jest za zakrętem.

(NOP) Farmaceutyczny Jugendamt? Kolejny powód żeby sprzeciwić się polityce rządu i wziąć udział w proteście 3 czerwca! (NOP)

(SLO) Oby tylko do tych badań nasi archeolodzy podeszli uczciwie i bez uprzedzeń rasowych typu „Słowianie i Polacy zawsze byli gorsi od Niemców i innych narodów”. 
Styl ten przybiera formy uroczyste. Fabularne formuły narracyjne służa opowiadaniu o spiskach i tajemnicach. W funkcji ekspertów występują postacie historyczne, naukowcy reprezentujący nauki społeczne, a także celebryci kojarzeni z dyskursem patriotycznym w mediach (niezależnie od realnych kompetencji); w świetle negatywnym stawiani są natychmiast naukowcy niezgadzający się z narracją „,narodową”.

(SLO) Jest to bardzo ważne, ponieważ część historyków polskich ośmiesza ideę Imperium Lechitów, poprzez interpretowanie tego organizmu prapaństwowego według wzorców imperialnych narzuconych przez narrację niewolniczego i zbrodniczego imperium rzymskiego. A narracja rzymska, niemiecka, wielko-brytyjska, US-owata oraz narracje innych żądnych tylko krwi i zysku narodów jest w naszej globalnej cywilizacji niestety na tak zwanym „topie”.

(NOP) Koło Konfederacja nie poprze w żadnym wypadku kolejnego totalniackiego projektu, jaki jest stręczony tej Izbie, stręczony w sposób godzien najgłębszego pożałowania, dlatego że w opakowaniu propagandowym, które w istocie służy antagonizowaniu Polaków i stygmatyzowaniu pewnej grupy ludzi, którzy starają się zachować jeszcze zdrowy rozsądek i zachować wolność w tym świecie, w którym totalniactwo przoduje i postępuje.

(CH) Właściwie dziś łacno rozpoznacie, kto ma w swoim umyśle geny polskie, a kto jest tu nawiezionym guanem. Takim probierzem jest stosunek do Pierwszej Rzeczpospolitej właśnie!

Często wykorzystywane są opozycje binarne wolność-opresja, swojskość-obcość, bezpieczeństwo-zagrożenie, patriotyzm-zdrada.

(NOP) uczmy się na błędach - getto warszawskie powstało właśnie pod pretekstem zagrożenia epidemiologicznego.

(NOP) Szanowni państwo, gdyby wszystko w Rzeczypospolitej nie sprzysięgło się przeciwko wolności i tradycjom narodowym, byśmy byli spokojni. Ale ta służba potocznie zwana sanepidem już teraz przejawia totalniackie zakusy wobec nas.

(RB) Byłoby idealnie, gdyby historycy zbadali pochodzenie naszego kraju. Aż dziwne, że do tej pory nikt publicznie nie ogłosił takich badań. Aby one dotarły do społeczeństwa, musi tego dokonać historyk ze znanym nazwiskiem. Takich osób nie brakuje po naszej stronie barykady.

- Stylistyka religijno-metafizyczna charakteryzuje się wykorzystywaniem słownictwa, ikonografii i symboliki religijnej oraz odwołaniami - językowymi i wizualnymi - do wartości eschatologicznych. Używa się tu opozycji binarnej wiara-wiedza, zdarzają się fatalistyczne odwołania do woli/ kary / opieki Bożej. Styl uroczysty bywa spleciony z naśladownictwem dyskursu biblijnego, w zaskakujący sposób współwystępujący z kolokwializmami.

(ZBA) Płaska ziemia rozbija wiarygodność szatana, jego władz i szatańskich mediów a także najwyższej rangi naukowców.

(ZBA) Co jest niezwykle interesujące, gnostycyzm nie posiada absolutnie żadnych dowodów na swoje dogmaty i właśnie ziemia kula jest jedynym pseudo dowodem na olbrzymi Wszechświat, w którym rzekomo istnieją wyimaginowani przez satanistów bogowie. Płaska ziemia jest więc koronnym dowodem na wszystkie fałszerstwa szatańskie, jakie nam szatan i upadli aniołowie zaserwowali.

(FPZ) jest to kluczowy temat naszego jestestwa , a sprawa jest prosta , bo system-matriks w którym wegetujemy ma swoje prawa, normy, religie, pragnienia, marzenia i wierzenia, a wszystkie mrówki robotnice musza być zaprzęgnięte do ciągnięcia tego wozu z królową i jej elitą, nasz padół-matriksgra-sims to więzienie, wiec tylko w elicie tego systemu mamy pokładać nadzieje na ucieczkę do 
Wielkiego Wszechświata, zdobywanie orbity, kosmosu, planet, bajki, animacje, fikcyjny pokarm edukacyjny od kołyski, stwórców inteligentnych nie ma, jesteśmy wypiardkami wielkiego wybuchu na zadupiu otchłani gdzie sposób na wyrwanie się stad ma tylko ELITA. A prawda jest całkiem inna, świat jest skonstruowany na innym fundamencie, jesteśmy pępkiem wszechświata, oczkiem w głowie swoich konstruktorów, choć ich morale świadczy o tym, że jesteśmy dla nich myszkami w laboratorium i mają oni przesłanki patologiczne, to jednak dbają i podlewają te kwiatki.

\section{Antynaukowość ironiczna}

Obok tych czterech modeli stylu werbalnego i wizualnego za niepokojące zjawisko należy uznać obecność w mediach para- i antynaukowego stylu ironicznego, cechującego się wieloznacznością, wykorzystaniem ironii i humoru lub też szoku, zaskoczenia. Autorzy wypowiedzi operują nadmiarem stylistycznym i estetycznym lub manipulują kontekstem i wskazówkami pozatekstowymi do zasygnalizowania dwuznacznego charakteru prezentowanych antynaukowych treści. Taki styl jest często używany w tekstach mających w rzeczywistości na celu walkę z dyskursem antynaukowym lub przynajmniej drwinę zeń lub bezinteresowną zabawę. To niebezpieczne, bo w sytuacji nadmiaru treści, szybkiego jej krążenia, nieuwagi lub ignorancji użytkowników ironiczne parodie antynaukowości zostają włączone do komunikowania grup antynaukowych i stają się częścią obiegu treści w tych grupach, zasilając dyskurs antynaukowy.

\section{Irracjonalność banalna}

Analiza ram konceptualnych nauki i antynaukowości miała ten dodatkowy walor, że uczuliła autorkę tych rozważań na zagadnienie irracjonalności w dyskursach medialnych w ogóle. Chodzi o te sytuacje komunikacyjne, gdy dziennikarze, politycy, marketingowcy, duchowni, nauczyciele, celebryci wyrażają przekonania i postawy antyracjonalne niejako mimochodem, bezwiednie, przy okazji. Takie wypowiedzi zdarzają się przypadkowo, ale miewają też charakter spontanicznej, niesamoświadomej ekspresji irracjonalizmu jako postawy życiowej. Niekiedy wynikają z przywiązania do tradycji, ale mogą też, jako wyraz zaufania do potocznej wiedzy tzw. szarego człowieka, służyć nawiązywaniu kontaktu z odbiorcami, wyborcami, klientami. Medialna widzialność wspiera ekspresję i uzasadnia prawomocność tego typu irracjonalizmu. W efekcie, w procesie przygotowania do analizy, zidentyfikowano jeszcze dwa typy irracjonalizmu występujące w dyskursach medialnych i wypowiedziach osób publicznych - niezależnie od ich tematyki i charakteru.

Irracjonalizm/antynaukowość przygodna charakteryzuje wypowiedzi niezgodne z wiedzą naukową lub odwołujące się do wiedzy fałszywej czy nieracjonalnych założeń o funkcjonowaniu rzeczywistości albo też kwestionujące wagę nauki na prawach przysłowia, żartu, anegdoty, tzw. mądrości ludowej. Niekiedy są one po prostu częścią potocznej frazeologii. Gdy jednak ważny polityk ogłasza, że wygrał wybory dzięki Bożej opiece lub wzywa, by się modlić za pozytywne rozwiązania publicznego kryzysu (Podtopienia, 2019), przygodny irracjonalizm zostaje usankcjonowany jako prawomocny sposób myślenia.

Irracjonalizm/antynaukowość banalna cechuje wypowiedzi antynaukowe lub antyracjonalne prezentowane jako część naturalizowanej, niekwestionowanej wiedzy o świecie i używane w funkcji identity statement czy autoprezentacji jednostki lub grupy. Znajdą się tu tego typu wypowiedzi, jak - odruchowe wśród wielu tzw. humanistów - chwalenie się kompletną nieznajomością nauk ścisłych (jakby to było coś pozytywnego) albo anegdoty o głupocie czy niekompetencji własnych (wspominanych) profesorów i nauczycieli. Poważniejsze jest ujmowanie relacji pomiędzy społeczeństwem a intelektualistami w kategoriach konfliktu i izolacji 
(np. kwestionowanie konieczności wydatków na naukę, gdy „dzieci nie mają co jeść”), podważanie sensowności badań podstawowych i teoretycznych, używanie pogardliwych lub obelżywych określeń wobec naukowców i intelektualistów (wykształciuchy, łże-elity). Wyrazem banalnego irracjonalizmu, który łatwo jest przeoczyć, jest też odwoływanie się do „zdrowego rozsądku” i wiedzy potocznej przy projektowaniu i wdrażaniu rozwiązań w rozmaitych sferach życia społecznego, podczas gdy dostępna jest użyteczna wiedza z badań naukowych.

\section{Zróżnicowanie stylów, wspólnota ramowania}

Reasumując, w komunikacji jednostek i organizacji podważających ustalenia racjonalnej nauki nowoczesnej splatają się cztery konceptualizacje nieufności: do nauki jako sposobu poznania; do konkretnych paradygmatów naukowych; do naukowców; do instytucji. Nieufność łączy się z eksponowaniem alternatywnych sposobów poznania oraz z głębokim brakiem zaufania do praktycznie wszelkich instytucji życia publicznego. Te cztery nieufności mogą być wyrażane za pomocą stylu i retoryki naukowej, religijnej, narodowej lub populistyczno-tabloidowej. Wszystkie rodzaje postaw i argumentacji oraz wszystkie style zidentyfikowano we wszystkich trzech korpusach. W komunikacji antyszczepionkowców daje się zaobserwować większą częstotliwość stylu quasi-naukowego i populistycznego; w komunikacji zwolenników turbosłowianizmu - quasi-naukowego i narodowego; w komunikacji płaskoziemców natomiast - populistycznego i religijnego, w zależności od źródeł (alternatywne poglądy na budowę Kosmosu mogą bowiem wypływać z przesłanek religijnych lub antyreligijnych; płaskoziemcy religijni i antyreligijni raczej się ze sobą nie mieszają, często zaś pozostają w aktywnym konflikcie). Ta pobieżna ocena ilościowa nie przybiera tu postaci szczegółowych wyliczeń, ponieważ jej statystycznie wiarygodne potwierdzenie wymaga znacznie bardziej zaawansowanych badań nad słownictwem, retoryką, obrazowaniem i wartościowaniem w analizowanych dyskursach.

Badania te będą konieczne ze względu na wagę problemu. Media bowiem nie tylko same w sobie są źródłem dyskursów irracjonalnych, ale również dostarczają przestrzeni do rozpowszechniania irracjonalizmu rozmaitym podmiotom zbiorowym. Pozwalają nie tylko na szerzenie antynaukowości, lecz także na jej instrumentalizację i wykorzystywanie do rozmaitych celów politycznych. W tej chwili w ich przestrzeni trwa zarówno destrukcja zaufania do nauki, jak i obrona jej wartości i znaczenia. Obowiązkiem medioznawców jest przyłączenie się do tej obrony.

\section{Bibliografia}

Bordwell, D., \& Thompson, K. (2010). Film Art. Sztuka filmowa. Kraków: Wydawnictwo Wojciech Marzec. Foley, R. (1987). The Theory of Epistemic Rationality. Harvard University Press.

Franczak, K. (2014). Perspektywa framing analysis - oferta analityczna dla badań nad dyskursem? Przeglą Socjologiczny, 63(3),135-156. Pobrane z http://cejsh.icm.edu.pl/cejsh/element/bwmeta1.element. desklight-c392bf3f-fc7b-4cee-9158-21d5c4427767.

Grundmann, R. (2017). The Problem of Expertise in Knowledge Societies. Minerva. A Review of Science, Learning and Policy, 55(1), 25-48. DOI:10.1007/s11024-016-9308-7.

Feyerabend, P. (1995). Przeciw metodzie. Nowa Krytyka 6, 105-178. 
Kamiński, S. (1992), Nauka i metoda. Pojęcie nauki i klasyfikacja nauk. W tegoż, Pisma wybrane, t. 4. Pobrane z https://dlibra.kul.pl/Content/31624/download/.

Lakatos, I. (1995). Falsyfikacja a metodologia naukowych programów badawczych. W tegoż, Pisma z filozofii nauk empirycznych. Warszawa: Wydawnictwo Naukowe PWN.

Mrozowski, M. (2001). Media masowe. Władza, rozrywka i biznes. Warszawa: Oficyna Wydawnicza ASPRA-JR.

Pinker, S. (2018). Nowe Oświecenie. Argumenty za rozumem, nauka, humanizmem i postępem. Poznań: Zysk i S-ka.

Podtopienia w Małopolsce. Premier: módlmy się, żeby ten deszcz przestał padać (2019). Polsat News, 23.05.2019, 21:34. Pobrane z https://www.polsatnews.pl/wiadomosc/2019-05-23/podtopienia-w-malopolsce-premier-wezmie-udzial-w-posiedzeniu-sztabu-kryzysowego/.]

Proctor, R.N., \& Schiebinger, L. (2008). Agnothology. The Making and Unmaking of Ignorance. Stanford University Press.

Tałasiewicz, M. (1995). O pojęciu „racjonalności” (I). Filozofia Nauki 3/1/2, 79-100. Pobrane z http://bazhum.muzhp.pl/media//files/Filozofia_Nauki/Filozofia_Nauki-r1995-t3-n1_2/Filozofia_Nauki-r1995t3-n1_2-s79-100/Filozofia_Nauki-r1995-t3-n1_2-s79-100.pdf

Tversky, A., \& Kahneman, D. (1973). Availability: A heuristic for judging frequency and probability. Cognitive Psychology 5(2), 207-232, 1973. DOI: 10.1016/0010-0285(73)90033-9.

Walczak, M. (2004). Wartościujący wymiar kategorii racjonalności nauki. Roczniki Filozoficzne, 52(2), $347-364$.

Walczak, M. (2006). Racjonalność nauki. Problemy, koncepcje, argumenty. Lublin: Towarzystwo Naukowe Katolickiego Uniwersytetu Lubelskiego.

Ziemińska, R. (2001). Alvina I. Goldmana teoria wiedzy i uzasadnienia. Roczniki Filozoficzne, 49(1), 77-107.

Życiński, J. (1985). Teizm i filozofia analityczna. T. 1. Kraków: Wydawnictwo „Znak”.

\section{Material źródłowy}

Forum Płaska Ziemia. Pobrane z http://forumplaskaziemia.pl/index.php.

Niezależne Forum - Cheops. Forum dla WSZYSTKICH. Pobrane z http://www.cheops4.org.pl/.

Płaska Ziemia, Nowy Porządek Świata \& Więcej. Pobrane z https://www.facebook.com/RealWorldInformations.

Polski Portal Informacyjny Robert Brzoza. Pobrane z http://robertbrzoza.pl/.

Polski Portal Informacyjny Robert Brzoza / Inne spojrzenie Marta Brzoza. Pobrane z https://martabrzoza.pl/.

Słowianie i Ukryta Historia Polski. Pobrane z http://slowianieiukrytahistoriapolski.pl/historia_lechii/turboslowianie_i_turbolechici/index.pl.html.

Polskie Stowarzyszenie Badaczy Płaskiej Ziemi. Pobrane z https://www.facebook.com/groups/8019415 29976646/.

Stowarzyszenie STOP NOP. Pobrane z http://stopnop.pl.

Zbawienie.pl. Pobrane z http://zbawienie.com/plaska-ziemia.htm. 